\title{
Pediatric Quality of Life in Congenital Hypothyroidism: an Indonesian Study
}

\author{
Nur Rochmah, Muhammad Faizi, Carrina Dewanti and Ahmad Suryawan \\ Department of Child Health, Dr. Soetomo General Hospital, Faculty of Medicine, Airlangga University, Surabaya, Indonesia
}

Background and Objectives: Thyroxine is important for brain development. Improper hypothyroid treatment may lead to cognitive and motor impairment, thereby affecting the quality of life. We analyzed the correlation between age at first treatment, length of treatment, initial levothyroxine (LT4) dose, and serum levels of free thyroxine (fT4) and thyroid stimulating hormone (TSH) and pediatric quality of life in patients with congenital hypothyroidism $(\mathrm{CH})$. Materials and Methods: This research was a cross-sectional study of 41 children with $\mathrm{CH}$ who consumed LT4 for at least 3 months during March 2019-December 2019. The quality of life was assessed from parents' reports using the Pediatric Quality of Life Inventory (PedsQL) generic scale. Spearman correlation analysis was carried out, and statistical significance was set at $p<0.05$. Results: A total of 17 of the 41 children were girls. The mean PedsQL scores in physical and psychosocial functioning were 78.12 (68.75-100) and 233.30 (215-251.67), respectively. Age at first treatment was correlated with physical functioning $(r=-0.501, p<0.05)$ and psychosocial functioning $(r=-0.440, p<0.05)$. The initial LT4 dose was negatively correlated with physical functioning $(r=-0.568, p<0.05)$ and psychosocial functioning $(r=-0.482, p<0.05)$. The length of treatment showed a positive correlation with physical functioning $(r=0.776, p<0.05)$ and psychosocial functioning $(r=$ $-0.852, p<0.05)$. However, the serum fT4 and TSH levels were not correlated with quality of life in children with $\mathrm{CH}(\mathrm{p}>0.05)$. Conclusion: Age at first treatment, initial dose of LT4, and length of treatment were correlated with quality of life in children with $\mathrm{CH}$.

Key Words: Congenital hypothyroidism, Child, Quality of life, PedsQL

\section{Introduction}

Thyroid hormone plays an important role in brain development. Hypothyroidism is a state of decreased or non-functioning thyroid gland to produce an appropriate amount of thyroid hormone to fulfil the body's metabolic needs. "It can occur as a result of primary gland failure or inadequate stimulation of the thyroid gland by the hypothalamus or pituitary gland. Congenital hypothyroidism $(\mathrm{CH})$ is one of the most common preventable causes of intellectual disability worldwide. ${ }^{2,3)}$ Its symptoms are typically subtle in

\section{infants. ${ }^{4,5}$}

The prevalence of $\mathrm{CH}$ is 1:4500 infants in the US, 1:3000 infants in Europe, 1:800 infants in Japan, 12, 6:1000 infants in Iran, and 1:257 in Pakistan. ${ }^{6-8)}$ Newborn screening for hypothyroidism was passed by the Ministry of Health Republic of Indonesia in 2014 (PMK No. 78/2014), ${ }^{9}$ and 1:3000 infants was diagnosed with $\mathrm{CH}^{10}{ }^{10)}$ The newborn baby screening program of CH from 2012 to 2013 at Cipto Mangunkusumo Hospital, Jakarta found that 14 of 3720 patients suffered from peripheral $\mathrm{CH}^{11)}$

Research on factors correlated with quality of life in $\mathrm{CH}$ remains inconsistent. This study aimed to evaluate

Received April 28, 2020 / Revised June 19, 2020 / Accepted June 19, 2020

Correspondence: Nur Rochmah, MD, Department of Child Health, Faculty of Medicine, Airlangga University, Prof. Dr Moestopo 6-8, Surabaya 60286, Indonesia

Tel: 62-817-03501118, Fax: 62-31-5022472, E-mail: drnurrochmah@gmail.com

Copyright (c) the Korean Thyroid Association. All rights reserved.

(1) This is an open-access article distributed under the terms of the Creative Commons Attribution Non-Commercial License (http://creative(c) 1 (1) commons.org/licenses/by-nc/4.0/), which permits unrestricted non-commercial use, distribution, and reproduction in any medium, provided the original work is properly cited. 
correlations between age at first treatment, length of treatment, initial levothyroxine (LT4) dose, and serum free thyroxine (fT4) and thyroid stimulating hormone (TSH) levels and pediatric quality of life in patients with $\mathrm{CH}$.

\section{Materials and Methods}

We examined 41 children with $\mathrm{CH}$ attending the pediatric endocrinology outpatient clinic during March-May 2019. This study was approved by the ethical committee of the Dr. Soetomo General Hospital, Surabaya, Indonesia (1013/KEPK/III/2019). The diagnosis of $\mathrm{CH}$ was obtained at recall on the basis of abnormal serum TSH and fT4 values. The inclusion criteria included children less than 18 years old, with a treatment duration of more than 3 months, and those who agreed to be included in this study.

Age at first treatment, length of treatment, initial dose of LT4, and serum FT4 and TSH levels at diagnosis were evaluated. The parents were interviewed about their child's quality of life using the Pediatric Quality of Life Inventory (PedsQL) 4.0 generic scale, for parents report questionnaire sectors. ${ }^{12)}$ The PedsQL 4.0 generic scale consists of 23 items that assess physical functioning (eight items), emotional functioning (five items), social functioning (five items), and school/nursery functioning (five items). The PedsQL scale evaluated physical and psychosocial (sum of emotional, social, and school) functioning. The score was assessed by summing all the number of items answered on the scales and linearly transformed to $0-100$ as follows: $0=100,1=75,2=50,3=25$, and $4=0 .{ }^{13)}$ The reference range value for thyroid function test was based on age, while doses of LT4 also based on age and body weight ${ }^{14,15)}$ The correlation among age at first treatment, length of treatment, initial LT4 dose, fT4 and TSH serum levels, and PedsQL scale was analyzed by using Spearman's test. $p$-value less than 0.05 was considered statistically significant. All the statistically significant results were analyzed by SPSS 17.0 software (IBM SPSS).

\section{Results}

The baseline characteristics of the patients are presented in Table 1. Of the 41 subjects, the median of age at first treatment was 12 months, while the length of treatments was 20 months. We had $85 \%$ patients with central congenital hypothyroid, while $15 \%$ was peripheral congenital hypothyroid. Among our subjects, congenital heart disease and Down syndrome occured in 11 and 3 children with $\mathrm{CH}$, respectively.

Pediatric quality of life every sector in our patients was shown in Table 2. Our patients have a mean quality of life score of more than 70 points in each sector

Table 1. Baseline characteristics

\begin{tabular}{llr}
\multicolumn{1}{c}{ Characteristics } & & Congenital hypothyroidism $(\mathrm{n}=41)$ \\
\hline Gender & $\mathrm{n}(\%)$ & $24(58.5)$ \\
Boy & & $17(41.5)$ \\
Girl & Median (IQR) & $12.0(1.0-80.0)$ \\
Age of initial treatment (month) & Median (IQR) \\
Length of treatment (month) & $\mathrm{n}(\%)$ & $20.0(6.0-54.0)$ \\
Initial LT4 doses & & $12(29.3)$ \\
$\leq 10$ mcg/kgBW & $\mathrm{n}(\%)$ & $29(70.7)$ \\
$>10$ mcg/kgBW & & $6(14.6)$ \\
Type of hypothyroidism & $\mathrm{n}(\%)$ & $35(85.4)$ \\
Peripheral & & $11(26.8)$ \\
Central & $3(7.3)$ \\
Comorbid & $27(65.9)$ \\
Congenital heart disease & & \\
Down syndrome & & \\
Without comorbid &
\end{tabular}

IQR: interquartile range 
with the highest score in the aspect of psychosocial functioning. The correlation among age at first treatment, length of treatment, initial dose of LT4, serum fT4 and TSH levels and PedsQL are described in Table 3. Age at first treatment, length treatment, and initial LT4 dose were positive correlated to five sectors of PedsQL.

\section{Discussion}

The correlation between age at first treatment and PedsQL in our study was significant. Early diagnosis and treatment yielded a better PedsQL score than late diagnosis and treatment (Table 3 ). Thus, early treatment ( $<13$ days) with initial LT4 more than 9.5 $\mathrm{mcg} / \mathrm{kgBW} /$ day could prevent the severity of psychomotor disorders. ${ }^{16)}$ By contrast, Pulungan et al. ${ }^{11)}$ and Ordooei et al. ${ }^{17)}$ reported that the age at first treatment is not significantly correlated with PedsQL. Neonatal $\mathrm{CH}$ screening programs allow early detection and treatment. ${ }^{18,19)}$ Late diagnosis and improper treatment

Table 2. Pediatric quality of life sectors

\begin{tabular}{lc}
\hline \multicolumn{1}{c}{ Parameters } & $\begin{array}{c}\text { Median } \\
\text { (interquartile range) }\end{array}$ \\
\hline Physical functioning & $78.1(68.7-87.5)$ \\
Social functioning & $75.0(70.0-80.0)$ \\
Emotional functioning & $75.0(65.0-80.0)$ \\
School/nursery functioning & $83.3(75.0-91.6)$ \\
Psychosocial functioning & $233.3(215.0-251.6)$ \\
\hline
\end{tabular}

may cause serious permanent cognitive and motor deficits, thereby affecting the quality of life, social life, emotions, behavior, and self-esteem of a patient. ${ }^{3,6,20)}$

The length of treatment was found to be correlated with PedsQL in this study, making it the most significant variable that affected the quality of life. Some studies supported this finding. ${ }^{21,22)}$

As shown in Table 1, most of our patients received LT4 dosage $>10 \mathrm{mcg} / \mathrm{kgBW} /$ day. The correlation between an initial dose of LT4 and PedsQL was significant. There was a controversial issue is the optimal initial dose of levothyroxine (LT4) for avoiding mental retardation with the minimum side effects. Several studies conclude that a high initial dose is beneficial and harmless. ${ }^{23-26)}$ Salerno et al ${ }^{26)}$ comparing initial LT4 dose $6.0-8.0 \mathrm{mcg} / \mathrm{kgBW} /$ day with $8.1-10.0 \mathrm{mcg} / \mathrm{kgBW} /$ day; and $10.1-15.0 \mathrm{mcg} / \mathrm{kgBW} /$ day. The results showed that there were no significant differences in height, weight, head circumference, and bone age maturation among the three groups of $\mathrm{CH}$ patients. There was no clinical signs nor symptoms of overtreatment observed during follow-up in higher LT4 dosage group. However, high LT4 starting doses rapidly normalize serum TSH concentrations thus resulting in an improvement of the IQ at 4 years of age, even in patients with severe $\mathrm{CH}$ at diagnosis. ${ }^{26)}$ Another study showed that optimal treatment with LT4 dose above $9.5 \mathrm{mcg} / \mathrm{kgBW} /$ day before 13 days of life, achieving euthyroid before third week of life then maintenance FT4 concentrations during the first year

Table 3. Correlation among factors associated with congenital hypothyroidism

\begin{tabular}{|c|c|c|c|c|c|}
\hline \multirow[b]{2}{*}{ Factors } & \multicolumn{5}{|c|}{ PedsQL } \\
\hline & $\begin{array}{c}\text { Physical } \\
\text { functioning }\end{array}$ & $\begin{array}{c}\text { Social } \\
\text { functioning }\end{array}$ & $\begin{array}{l}\text { Emotional } \\
\text { functioning }\end{array}$ & $\begin{array}{l}\text { School/nursery } \\
\text { functioning }\end{array}$ & $\begin{array}{l}\text { Psychosocial } \\
\text { functioning }\end{array}$ \\
\hline $\begin{array}{l}\text { Age at first } \\
\text { treatment* }\end{array}$ & $(r=-0.568$ & $(r=-0.343$ & $=-0.315$, & $=0.045$ & $(r=-0.440$ \\
\hline $\begin{array}{l}\text { Length } \\
\text { treatment* }\end{array}$ & $(r=0.776, p=0.000)$ & $(r=0.719, p=0.000)$ & $(r=0.603, p=0.000)$ & $(r=0.757, p=0.000)$ & $(r=0.852, p=0.000)$ \\
\hline $\begin{array}{l}\text { Initial dose } \\
\text { of LT4* }\end{array}$ & $(r=-0.568, p=0.000)$ & $(r=-0.492, p=0.001)$ & $(r=-0.337, p=0.031)$ & $(r=-0.296, p=0.061$ & $(r=-0.482, p=0.001)$ \\
\hline fT4 & $(r=0.169, p=0.291)$ & $(r=0.109, p=0.499)$ & $(r=0.202, p=0.206)$ & $(r=0.097, p=0.546)$ & $(r=0.153, p=0.338)$ \\
\hline $\mathrm{TSH}$ & $(r=-0.286, p=0.070)$ & $(r=-0.308, p=0.050)$ & $(r=0.005, p=0.976)$ & $(r=-0.221, p=0.166$ & $(r=-0.225, p=0.158)$ \\
\hline
\end{tabular}

fT4: free thyroxine, LT4: levothyroxine, PedsQL: Pediatric Quality of Life Inventory, TSH: thyroid stimulating hormone Statistics were carried out using Spearman's test.

*Statistically significant correlated. 
will achieve normal psychomotor development at 10 to 30 months, irrespective of the severity of $\mathrm{CH}^{23)}$ Nonetheless, other authors have shown a dual effect of an initial high dose. A higher starting dose level of LT4 also contributed to more behavior problems in spite of better learning ability. ${ }^{27)}$

Our study showed that patients have high mean of quality of life (Table 2). It may caused by more patients treated with initial high doses than low doses. Early LT4 treatment (dose $>9.5 \mathrm{mcg} / \mathrm{kgBW} /$ day) is correlated with mental and psychomotor development. ${ }^{13,23)}$ Rovet et al. ${ }^{27)}$ showed that underdosage of thyroxine may cause learning disabilities and psychoeducational problems. In addition, Alvarez et al. ${ }^{28)}$ and Craven et al. ${ }^{29)}$ and Vaidyanathan et al. ${ }^{30)}$ reported that LT4 overtreatment may cause attention disorder and inhibitory control at school age and biochemical hyperthyroidism at follow up.

Higher score of quality of life may be due to the subtle clinical manifestations of central $\mathrm{CH}$ frequently observed in our study. Central $\mathrm{CH}$ is more difficult to diagnose than peripheral $\mathrm{CH}$, and it is commonly diagnosed late. ${ }^{18)}$ This finding differed from a previous report, which stated that peripheral $\mathrm{CH}$ is more prevalent than central $\mathrm{CH}^{31}{ }^{31)}$ This difference may be due to the status of our hospital being a national tertiary referral hospital in the east Indonesian region.

In this study, the correlation of the initial serum fT4 and TSH levels with quality of life in $\mathrm{CH}$ based on parents' reports was not significant. Klaver et al. ${ }^{32)}$ and Kelderman-Bolk et al. ${ }^{33)}$ also revealed that TSH and fT4 values do not significantly affect the quality of life. Unlike our results, the findings of other studies indicated a correlation between serum TSH and fT4 levels and PedsQL. ${ }^{21,22)}$ The improvement of TSH and fT4 was influenced by treatment compliance, initial doses of LT4, age at first treatment, and severity of the disease. ${ }^{22)}$ Several studies showed the decreased quality of life in hypothyroidism. ${ }^{34,35)}$ Therefore, newborn screening of $\mathrm{CH}$ and regular visits for patients with $\mathrm{CH}$ are critical. Regular monthly visits (infants under 6 months of life) are recommended, continued with regular visits every 2 months until 1 year old and every 3-4 months until 3 years old.,14)
Children with $\mathrm{CH}$ in our study had some comorbidities. Of the 41 subjects in our study, there were congenital heart disease (26.8\%) and Down syndrome (7.3\%) co-occuring $\mathrm{CH}$. Razavi et al. ${ }^{36)}$ showed congenital anomalies in $20 \%$ of 150 infants with $\mathrm{CH}$. Down syndrome, congenital heart disease and development dysplasia of the hip were the most congenital malformations co-occuring $\mathrm{CH}$.

We conclude that age at first treatment, initial dose of LT4, and length of treatment are correlated with quality of life in children with $\mathrm{CH}$. Our study had some limitations. We had small sample size in single pediatric endocrinologist out patients clinic centre. We did not evaluate IQ of the CH patient and correlated with QoL. Therefore, multicenter studies are needed to determine the QoL of $\mathrm{CH}$ in long term outcomes of treatment.

\section{Acknowledgments}

The authors thank to the patients who participated in the study and the endocrine teams of Dr. Soetomo General Hospital, Surabaya, Indonesia, for the support.

\section{Conflicts of Interest}

No potential conflict of interest relevant to this article was reported.

\section{Orcid}

Nur Rochmah: https://orcid.org/0000-0002-9626-9615

Muhammad Faizi: https://orcid.org/0000-0002-1208-0744 Carrina Dewanti: https://orcid.org/0000-0003-3236-598X Ahmad Suryawan: https://orcid.org/0000-0002-3377-0381

\section{References}

1) Gaitonde DY, Rowley KD, Sweeney LB. Hypothyroidism: an update. Am Fam Physician 2012;86(3):244-51.

2) Counts D, Varma SK. Hypothyroidism in children. Pediatr Rev 2009;30(7):251-8.

3) Bhattacharya A. Congenital hypothyroidism and developmental difficulties. Gen Med Open Access 2013;1(1):1-4.

4) Rahmani K, Yarahmadi S, Etemad K, Koosha A, Mehrabi Y, Aghang N, et al. Congenital hypothyroidism: optimal initial dosage and time of initiation of treatment: a systematic review. 
Ped QoL in Congenital Hypothyroidism

Int J Endocrinol Metab 2016;14(3):e36080.

5) Olivieri A, Fazzini C, Medda E, Italian Study Group for Congenital Hypothyroidism. Multiple factors influencing the incidence of congenital hypothyroidism detected by neonatal screening. Horm Res Paediatr 2015;83(2):86-93.

6) Kaye CI, Committee on Genetics; Accurso F, La Franchi S, Lane PA, Northrup $\mathrm{H}$, et al. Introduction to the newborn screening fact sheets. Pediatrics 2006;118(3):1304-12.

7) Keshavarzian E, Valipoor AA, Maracy MR. The incidence of congenital hypothyroidism and its determinants from 2012 to 2014 in Shadegan, Iran: a case-control study. Epidemiol Health 2016;38:e2016021.

8) Ahmad A, Wasim A, Hussain S, Saeed M, Ahmad BM, Rehman KU. Congenital hypothyroidism in neonates of a tertiary care hospital. Pak J Med Sci 2017;33(5):1269-72.

9) Indonesian Ministry of Health. Ministreal Decree no.78 issued on 2014. [Internet] 2016 Oct 03 [cited January 11, 2020]. Available from URL: http://kesga.kemkes.go.id.

10) Indonesian Ministry of Health. Skrining Hipotiroid Kongenital. Jakarta: Indonesian Ministry of Health; 2014. p.1-66.

11) Pulungan AB, Oldenkamp ME, van Trotsenburg ASP, Windarti W, Gunardi H. Effect of delayed diagnosis and treatment of congenital hypothyroidism on intelligence and quality of life : an observational study. Med J Ind 2019;28(4): 396-401.

12) Varni JW, Burwinkle TM, Seid M. The PedsQL as a pediatric patient-reported outcome: reliability and validity of the PedsQL Measurement Model in 25,000 children. Expert Rev Pharmacoecon Outcomes Res 2005;5(6):705-19.

13) Varni JW. Measurement model for the pediatric quality of life inventory. [Internet] 2020 [cited May 26, 2020]. Available from URL: http://pedsql.org.

14) Soghier L, Pham K, Rooney S. Reference range values for pediatric care. United State: American Academy of Pediatrics; 2014. p.97.

15) Huang SA. Thyroid. In: Kappy MS, Allen DB, Geffner ME, editors. Pediatric practice endocrinology. 1st ed. New York: Mc Graw Hill, 2010. p.107-29.

16) Bongers-Schokking JJ, Koot HM, Wiersma D, Verkerk PH, de Muinck Keizer-Schrama SM. Influence of timing and dose of thyroid hormone replacement on development in infants with congenital hypothyroidism. J Pediatr 2000;136(3):292-7.

17) Ordooei M, Mottaghipisheh H, Fallah R, Rabiee A. Cognitive outcomes for congenital hypothyroid and healthy children: a comparative study. Iran J Child Neurol 2014;8(4):28-32.

18) Hanley P, Lord K, Bauer AJ. Thyroid disorders in children and adolescents: a review. JAMA Pediatr 2016;170(10):1008-19.

19) Jacob H, Peters C. Screening, diagnosis and management of congenital hypothyroidism: European Society for Paediatric Endocrinology consensus guideline. Arch Dis Child Educ Pract Ed 2015;100(5):260-3.

20) Rovet J. Congenital hypothyroidism: treatment and outcome. Curr Opin Endocrinol Diabetes Obes 2005;12:42-52.

21) Park ES, Yoon JY. Factors associated with permanent hypothyroidism in infants with congenital hypothyroidism. BMC Pediatr 2019;19(1):453.

22) Soliman AT, Azzam S, Elawwa A, Saleem W, Sabt A. Linear growth and neurodevelopmental outcome of children with congenital hypothyroidism detected by neonatal screening: a controlled study. Indian J Endocrinol Metab 2012;16(4):565-8.

23) Bongers-Schokking JJ, Resing WCM, Oostdijk W, de Rijke YB, de Muinck Keizer-Schrama S. Relation between early over- and undertreatment and behavioural problems in preadolescent children with congenital hypothyroidism. Horm Res Paediatr 2018;90(4):247-56.

24) Kooistra L, Vulsma T, van der Meere J. An investigation of impulsivity in children with early-treated congenital hypothyroidism. Dev Neuropsychol 2004;26(2):595-610.

25) Selva KA, Harper A, Downs A, Blasco PA, Lafranchi SH. Neurodevelopmental outcomes in congenital hypothyroidism: comparison of initial T4 dose and time to reach target T4 and TSH. J Pediatr 2005;147(6):775-80.

26) Salerno M, Militerni R, Bravaccio C, Micillo M, Capalbo D, Di MS, et al. Effect of different starting doses of levothyroxine on growth and intellectual outcome at four years of age in congenital hypothyroidism. Thyroid 2002;12(1):45-52.

27) Rovet JF, Ehrlich R. Psychoeducational outcome in children with early-treated congenital hypothyroidism. Pediatrics 2000; 105(3 Pt 1):515-22.

28) Alvarez M, Iglesias Fernandez C, Rodriguez Sanchez A, Dulin Lniguez E, Rodriguez Arnao MD. Episodes of overtreatment during the first six months in children with congenital hypothyroidism and their relationships with sustained attention and inhibitory control at school age. Horm Res Paediatr 2010;74(2):114-20.

29) Craven M, Frank GR. Does initial dosing of levothyroxine in infants with congenital hypothyroidism lead to frequent dose adjustments secondary to iatrogenic hyperthyroidism on follow-up? J Pediatr Endocrinol Metab 2018;31(6):597-600.

30) Vaidyanathan P, Pathak M, Kaplowitz PB. In congenital hypothyroidism, an initial L-thyroxine dose of $10-12 \mathrm{mug} / \mathrm{kg} /$ day is sufficient and sometimes excessive based on thyroid tests 1 month later. J Pediatr Endocrinol Metab 2012;25(9-10):849-52.

31) Sanjay S. Congenital hypothyroidism. IntechOpen 2019:6-15.

32) Klaver EI, van Loon HC, Stienstra R, Links TP, Keers JC, Kema IP, et al. Thyroid hormone status and health-related quality of life in the LifeLines cohort study. Thyroid 2013; 23(9):1066-73.

33) Kelderman-Bolk N, Visser TJ, Tijssen JP, Berghout A. Quality of life in patients with primary hypothyroidism related to BMI. Eur J Endocrinol 2015;173(4):507-15.

34) Ahmed ME, Elsaayed W, Ali R, Mohamed M. Developmental outcomes in early-treated congenital hypothyroidism: specific concern in Tc99m thyroid scan role. Int J Pediatr 2019;7(6): 9631-43.

35) van der Sluijs Veer L, Kempers MJ, Last BF, Vulsma T, Grootenhuis MA. Quality of life, developmental milestones, and self-esteem of young adults with congenital hypothyroidism diagnosed by neonatal screening. J Clin Endocrinol Metab 2008; 93(7):2654-61.

36) Razavi Z, Yavarikia A, Torabian S. Congenital anomalies in infant with congenital hypothyroidism. Oman Med J 2012;27(5): 364-7. 